\title{
CADA DETENTO UMA MÃE, UMA CRENÇA, CADA CRIME UMA SENTENÇA, CADA SENTENÇA UM MOTIVO־: PRESCRIÇÃO PENAL E SUA APLICAÇÃO NO DIREITO PENAL BRASILEIRO CONTEMPORÂNEO
}

\author{
Diogo dos Santos Martins ${ }^{2}$ \\ Chaienne Gomes ${ }^{3}$ \\ Genilson da Rocha Matos 4 \\ Isabela Rodrigues da Silva 5 \\ Layla Rayza Sampaio Pontes 6 \\ Luciano Rocha dos Santos ${ }^{7}$ \\ Stéphane Rodrigues Cardoso ${ }^{8}$
}

RESUMO: Trata-se de trabalho apresentado à matéria Direito Penal - Teoria da pena sobre o instituto da prescrição penal. Para chegar ao ponto culminante da discussão do tema em tela, buscou-se primeiramente esclarecer conceitos importantes como o jus pudiendi estatal, o Estado como detentor do direito punitivo, abordou-se os limites deste poder punitivo, apresentando a linha tênue que divide a prepotência estatal e os direitos e garantias individuais, para isso foi desempenhada uma abrangente pesquisa em obras que concerne ao tema. Para terminar, logo após tratar sobre os limites estatais e as legitimidades de suas intervenções, buscou-se afunilar o tema para realizar uma discussão teórica mais robusta acerca do instituto da prescrição penal.

Palavras-chave: Prescrição. Prescrição Penal. Prescrição Penal e sua aplicação.

\section{INTRODUÇÃO}

A prescrição penal, é a perda do direito do estado de punir alguma conduta, depois de um dado período, tendo em vista que esse dever deve ser exercido dentro de um prazo legalmente estabelecido. A prescrição penal não é contra ao titular da ação penal, mas contra ao Estado, como o Estado não exerceu seu direito de punir no prazo

\footnotetext{
I Trecho da letra de Diário de um detento - Jocenir e Mano Brown: Racionais MC's

${ }^{2}$ Universidade Federal do Recôncavo da Bahia, Bacharelando em Direito.

${ }^{3}$ Centro Universitário Nobre de Feira de Santana, Bacharelando em Direito

${ }^{4}$ Centro Universitário Nobre de Feira de Santana, Bacharelando em Direito

5 Centro Universitário Nobre de Feira de Santana, Bacharelando em Direito

${ }^{6}$ Centro Universitário Nobre de Feira de Santana, Bacharelando em Direito

7 Centro Universitário Nobre de Feira de Santana, Bacharelando em Direito

${ }^{8}$ Centro Universitário Nobre de Feira de Santana, Bacharelando em Direito
} 
determinado pela lei, ele perde a legitimidade de usar seu direito de punição. Como houve um lapso de tempo e a inercia do Estado, extingue-se a punibilidade do agente, impedindo assim a aplicação da pena contra ele.

A prescrição extintiva pode ser classificada em dois gêneros: prescrição da pretensão punitiva e prescrição da pretensão executória. Para ambos os casos deverá ser consultado o prazo prescricional estabelecidos no art.ıog do Código Penal.

O jus puniendi é uma expressão que pode ser entendida como o direito de punir do Estado, como ente dotado de soberania, detém exclusivamente este direito de punir. O jus puniendi é o que estabelece a relação ativa entre o Estado é o sujeito ativo do crime.

O Estado passa a ter interesse em alterar o direito à liberdade daquele infrator, para que ele tenha a punição. O surgimento de uma relação jurídica com o infrator, faz com que o direito de punir saia do plano abstrato e se concretize.

Punibilidade é a possibilidade jurídica de o Estado impor sanção penal diante de um crime ou contravenção penal, no exercício do jus puniendi, ou seja, seu direito exclusivo de punir tais condutas dentro de prazos determinados. Existe um prazo para satisfazer a pretensão punitiva e outra para executar a punição imposta, este prazo é chamado de prescrição, que é justamente, a perda da pretensão concreta de punir o criminoso ou de executar a punição, devido à inércia do Estado durante determinado período.

O objetivo desse trabalho é salientar algumas dúvidas desse tema como: Os prazos da prescrição penal, causas interruptivas da prescrição, diferenciar os dois gêneros da prescrição extintiva, crimes que não prescrevem, os efeitos da prescrição e da pretensão punitiva.

Neste artigo iremos abordar os fundamentos históricos e políticos da prescrição, prescrição da pena de multa, termo inicial da prescrição e causas modificadoras do curso prescricional, espécies da prescrição e jurisprudências. 


\section{FUNDAMENTOS HISTÓRICOS E POLÍTICOS DA PRESCRIÇÃO}

Incialmente, insta salientar que o instituto jurídico da prescrição está legalmente previsto no art. I07, IV do Código Penal. Deste modo, tem-se como sentindo genérico no que concerne direito a prescrição, o significado da perda de uma pretensão, pelo decurso de tempo. Segundo o autor Basileu Garcia, a prescrição é: “a renúncia do Estado a punir a infração, em face do decurso do tempo.”

Sabe-se que a primeira menção ao termo prescrição a ser feita, foi registrada no Código Criminal na época do Império do Brasil em 1830, o qual dispunha apenas o artigo 65 que diz: "as penas impostas aos réus não prescreverão em tempo algum.” Ademais, vale ressaltar que até a supracitada data não existia na legislação pátria o instituto jurídico ora em estudo, de modo que se passaram as regras indígenas, as Ordenações do Reino, Afonsinas, Manuelinas, Filipinas e o Direito do BrasilHolandês.

Nesta senda, a prescrição penal foi processada bem lentamente ao longo dos séculos, sendo apenas regulamentada no Código de Processo Criminal no ano de I832, com as leis posteriores, considerados prazos maiores para os crimes inafiançáveis e menores para os crimes afiançáveis, influenciando-se pela presença ou ausência do réu para sua fixação.

Outrossim, com o advento da Lei n. ${ }^{\circ}$ 26I, de 03 de dezembro de 184 I e do Regulamento n. ${ }^{\mathrm{o}}$ 120, de $3 \mathrm{I}$ de janeiro de 1842 , trouxe uma maior severidade acerca da temática da prescrição, estabelecendo-se como prazo único de 20 anos. No que concerne crimes imprescritíveis, tem-se como requisito da presença do delinquente para o reconhecimento da prescrição. Já a prescrição da condenação somente foi instituída em 1890 pelo Decreto de $\mathrm{n}^{\circ}$. 774 , que discriminava os prazos da prescrição com base no tempo da pena. Com os Códigos Penais de 1890 e 1940 consagrou-se as duas modalidades de prescrição, assim como no Código Penal vigente, de 1984 .

Portanto, a Constituição Federal de 1988 estabeleceu em seu artigo 5ำ, incisos XLII e XLIV, a imprescritibilidade dos crimes de racismo e de ação de grupos armados 
contra a ordem constitucional e ao Estado Democrático. Isso porque, o legislador constituinte considerou que tais delitos afetam os institutos basilares da Carta Magna, merecendo assim reprovação social a qualquer tempo.

Entende-se a prescrição como instrumento de política criminal comum a grande maioria dos ordenamentos jurídicos, no que concerne a temática da perda do direito-dever do Estado de punir o acusado por conta do transcurso de determinado lapso temporal previsto normativamente.

Destarte, é sabido que a inércia do Poder Público em consonância com seus órgãos, com a finalidade de investigar, processar e executar criminalmente o indivíduo acarreta, portanto, no desaparecimento do direito de punir. É dizer, com a materialização do instituto da prescrição advém a perda do direito sancionatório, o que difere substancialmente das hipóteses de renúncia a este direito.

Deste modo, acredita-se, que o esforço do Poder Público em manejar determinadas situações criminais já abarcadas pela prescrição, é uma tentativa desesperada de contorná-las, a fim de evitar a impunidade. Em destaque temos, caso do médium João de Deus, o qual foi acusado de inúmeros crimes contra a liberdade sexual no município de Abadiânia-GO. Sem entrar nos pormenores de eventual extrapolação do prazo decadencial em relação aos crimes supostamente praticados antes da vigência da Lei $\mathrm{n}$ o 13.718 , de 2018, tendo em vista a necessidade de representação para oferecimento da denúncia, parcela significativa dos delitos denunciados, como noticiado, teria ocorrido há muitos anos e, por conta disto, já alcançados pelo prazo prescricional.

Dessa maneira, vieram à tona as eventuais consequências oriundas destes crimes já prescritos junto à cobrança da sociedade em impedir que estes fatos terminem impunes. Por conta disto, se veiculou na imprensa por agentes públicos que, apesar da materialização da prescrição punitiva em parcela significativa dos crimes denunciados à mídia, ainda assim, as declarações prestadas por estas vítimas serviriam como elemento probatório a ser empregado em eventual processo criminal. 
Ademais, cabe ainda relembrar que a legislação penal prevê duas espécies de prescrição, a saber: a prescrição da pretensão punitiva e prescrição da pretensão executória. A escorreita distinção é fundamental na análise dos efeitos decorrentes do seu reconhecimento.

Em consideração as vítimas que sofreram pelos crimes praticados, tem-se o sentimento de injustiça que sempre prevalecerá, assim como o da sociedade em geral. Entretanto, o Judiciário, é o maior defensor da legalidade, visto que exerce sempre que necessário o seu papel contra majoritário, aplicando e interpretando as leis, por mais sensível que seja o caso concreto.

\section{ESPÉCIES DE PRESCRIÇÃO}

Mediante construção doutrinária, a prescrição pode ser dividida em duas espécies: a prescrição da pretensão punitiva (se dá antes do trânsito em julgado da sentença) e a prescrição da pretensão executória (se dá após o referido trânsito).

\section{3.r. PRESCRIÇÃO DA PRETENSÃO PUNITIVA}

Como já exposto, só poderá ocorrer antes do trânsito em julgado da sentença penal e tem como principal consequência à eliminação de todos os efeitos do crime, como se ele não tivesse existido. Esse tipo de prescrição extingui o direito de punir do Estado, quer impedindo-o de acionar o Poder Judiciário na busca da aplicação da lei penal ao fato cometido pelo agente, ou, caso exercido o direito de ação, é impedido de ver julgado, definitivamente, o processo em curso.

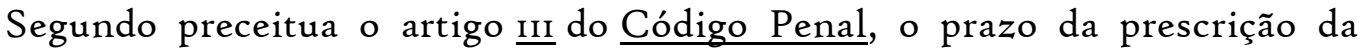
pretensão punitiva começa a fluir:

\footnotetext{
Art. III - A prescrição, antes de transitar em julgado a sentença final, começa a correr:

I - do dia em que o crime se consumou;

II - no caso de tentativa, do dia em que cessou a atividade criminosa;

III - nos crimes permanentes, do dia em que cessou a permanência;

IV - nos de bigamia e nos de falsificação ou alteração de assentamento do registro civil, da data em que o fato se tornou conhecido;
} 
$\mathrm{V}$ - nos crimes contra a dignidade sexual de crianças e adolescentes, previstos neste Código ou em legislação especial, da data em que a vítima completar I8 (dezoito) anos, salvo se a esse tempo já houver sido proposta a ação penal.

A prescrição da pretensão punitiva se subdivide em: abstrata, superveniente ou intercorrente e retroativa.
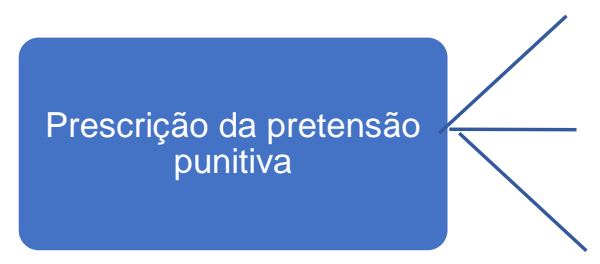

Em abstrato ou propriamente dita

\section{Superveniente (intercorrente)}

\section{Retroativa}

Fonte: Manual de Direito Penal - Parte Geral (Arts. Io ao I20), p. 243, Adaptado.

\section{3.r.I. PRESCIÇÃO DA PRETENSÃO PUNITIVA ABSTRATA}

A prescrição da pretensão punitiva abstrata recebe este nome porque o seu prazo regula-se pela pena em abstrato, ou seja, pelo máximo da pena privativa de liberdade cominada no tipo legal, de acordo com a tabela do artigo Iog do Código Penal.

Art. I09. A prescrição, antes de transitar em julgado a sentença final, salvo o disposto no $\S \mathrm{I}^{\circ}$ do art. IIo deste Código, regula-se pelo máximo da pena privativa de liberdade cominada ao crime, verificando-se:

I - em vinte anos, se o máximo da pena é superior a doze;

II - em dezesseis anos, se o máximo da pena é superior a oito anos e não excede a doze;

III - em doze anos, se o máximo da pena é superior a quatro anos e não excede a oito;

IV - em oito anos, se o máximo da pena é superior a dois anos e não excede a quatro;

$\mathrm{V}$ - em quatro anos, se o máximo da pena é igual a um ano ou, sendo superior, não excede a dois;

VI - em 3 (três) anos, se o máximo da pena é inferior a I (um) ano.

Prescrição das penas restritivas de direito 
Parágrafo único - Aplicam-se às penas restritivas de direito os mesmos prazos previstos para as privativas de liberdade.

Este tipo de prescrição só pode ocorrer entre a data da consumação do crime e o recebimento da denúncia ou da queixa, ou a partir desse momento até a sentença.

Por exemplo: se o crime é o de furto simples (artigo 155, caput, do Código Penal), apenado com reclusão de I (um) a 4 (quatro) anos, tem-se que o máximo de pena cominado à infração é de 4 (quatro) anos. Agora, ao verificar, no artigo ıo9, do mesmo diploma, o prazo prescricional correspondente, nota-se, no inciso IV que o crime prescreverá, de acordo com este tipo de prescrição em 8 (oito) anos.

Assim, ainda em referência ao exemplo supracitado, se ao momento do oferecimento da denúncia, já tiver transcorrido o prazo de 8 (oito) anos a contar da data do fato, o crime já estará prescrito, devendo o Ministério Público requerer o arquivamento dos autos, com base na extinção de punibilidade. Se não o fizer, pode o juiz conhecer ex officio a prescrição ou ela pode ser alegada em resposta à acusação.

Também estará prescrito o crime, no caso em tela, se já tiverem decorrido os 8 (oito) anos entre o recebimento da denúncia e a sentença.

\subsubsection{PRESCRIÇÃO DA PRETENSÃO PUNITIVA SUPERVENIENTE OU INTERCORRENTE}

Diferentemente da prescrição da pretensão punitiva abstrata, a intercorrente leva em conta para o cálculo do prazo prescricional a pena aplicada in concreto. $\mathrm{O}$ marco inicial dessa contagem se dá com a publicação da sentença condenatória recorrível e termina com o trânsito em julgado definitivo.

Insta salientar que é requisito que a sentença transite em julgado apenas para acusação e não também para a defesa, ou, ainda, depois de provido o recurso da acusação.

Se apenas a defesa interpôs recurso contra a sentença condenatória, segue-se que a pena não poderá ser majorada, por força do princípio que veda a reformatio in pejus. Logo, a pena aplicada define o prazo prescricional. O que se deve verificar, nessa hipótese de prescrição superveniente, é se, entre a data da sentença condenatória e o julgamento do recurso da defesa, ocorreu a prescrição, cujo prazo é 
calculado pelo enquadramento da pena [em concreto] em um dos incisos do art. Io9 do Código Penal.

Quanto ao improvimento do recurso da acusação, entre a data da sentença e o julgamento do tribunal que não prover o recurso, não poderá ultrapassar o prazo prescricional calculado de acordo com a pena aplicada na sentença ao agente.

Caso o recurso da acusação seja provido, ainda assim é possível entender que ocorra a prescrição da pretensão punitiva intercorrente se a decisão não elevar a pena ao passo de modificar o prazo prescricional. Exemplifica-se: o réu é condenado à pena de 3 (três) meses de detenção; acusação e defesa recorrem da decisão; passados 4 (quatro) anos, o tribunal acolhe o pedido da acusação e eleva a pena a ıo (dez) meses. Tanto a primeira pena, quanto a segunda, são inferiores a I (um) ano, assim, estão inseridas no mesmo inciso do artigo ıog do Código Penal, o VI, que estipula o prazo prescricional em 3 (três) anos. Desta maneira, tendo em vista que o tribunal decidiu os recursos passados 4 (quatro) anos da data da sentença, conclui-se que está extinta a punibilidade, em decorrência da prescrição superveniente.

\section{I.3. PRESCRIÇÃO DA PRETENSÃO PUNITIVA RETROATIVA}

Como a prescrição intercorrente é calculada pela pena em concreto, obtida na sentença penal e é necessário o trânsito em julgado para a acusação ou o não provimento de seu recurso.

Ainda que se verifiquem muitas semelhanças entre esses dois institutos, a grande diferença se encontra no fato de que ao passo que a intercorrente é calculada a partir da sentença, ou seja, para os períodos posteriores, a retroativa se volta ao passado, aos momentos anteriores à sentença.

Este tipo de prescrição da pretensão punitiva é criação da jurisprudência nacional, uma vez que não está expressa no texto legal.

Antes da reforma no Código Penal trazida pela Lei 12.234/2009, a prescrição retroativa tinha como termo inicial, ainda que somente reconhecida após o trânsito em julgado da sentença para a acusação, data anterior ao recebimento da denúncia ou queixa (artigo $\underline{\underline{I 1}}, \underline{\text { 2 }} \underline{\underline{0}}, \underline{\mathrm{CP}}$ ), ou seja, a data da consumação do crime. 
No entanto, com o avento da supracitada lei, o $\$ 2^{\circ}$ foi revogado e o primeiro alterado a fim de não mais poder a prescrição retroativa alcançar a data do fato.

Atualmente, a prescrição retroativa possui apenas um lapso prescricional, que é entre a data da sentença e o recebimento da denúncia ou queixa. Obviamente que excetuados os casos de crimes julgados pelo Tribunal do Júri, os crimes dolosos contra a vida, que em seu procedimento contam com mais dois marcos interruptivos: a pronúncia e a decisão confirmatória da pronúncia.

\subsection{PRESCRIÇÃO DA PRETENSÃO EXECUTÓRIA}

A pretensão executória (art. IIo, caput, do CP) se dá a partir do trânsito em julgado da sentença penal condenatória e pela pena in concreto. A sua ocorrência gera a perda do Estado de executar a pena imposta ao condenado, diante do transcorrer do prazo prescricional estipulado.

Art. ııo - A prescrição depois de transitar em julgado a sentença condenatória regula-se pela pena aplicada e verifica-se nos prazos fixados no artigo anterior, os quais se aumentam de um terço, se o condenado é reincidente.

Ainda que o condenado fique livre do cumprimento da pena, a prescrição da pretensão executória não afasta os efeitos secundários da sentença condenatória, como, por exemplo, a reincidência.

Com base no artigo in do Código Penal, o prazo começa a ser contado do dia em que:

Art. II2 - No caso do art. IIo deste Código, a prescrição começa a correr:

I - do dia em que transita em julgado a sentença condenatória, para a acusação, ou a que revoga a suspensão condicional da pena ou o livramento condicional;

II - do dia em que se interrompe a execução, salvo quando o tempo da interrupção deva computar-se na pena.

Importante observar a ressalva do penalista Cezar Bitencourt ao disposto no item (I):

O prazo começa a correr do dia em que transitar em julgado a sentença condenatória para a acusação, mas o pressuposto básico para essa espécie de prescrição é o trânsito em julgado para acusação e defesa, pois, enquanto não transitar em julgado para a defesa, a prescrição poderá ser a 
intercorrente. Nesses termos, percebe-se, que podem correr paralelamente dois prazos prescricionais: o da intercorrente, enquanto não transitar definitivamente em julgado; e o da executória, enquanto não for iniciado o cumprimento da condenação, pois ambos iniciam na mesma data, qual seja, o trânsito em julgado para a acusação.

\section{TERMO INICIAL DA PRESCRIÇÃO}

Ponderando a linha do artigo II2, inciso I, do Código Penal no qual em pauta esclarece de forma relevante sobre o termo inicial da prescrição da pretensão executória ao nível que se dá ao trânsito em julgado da sentença condenatória para a acusação, ao passo que sua aplicabilidade pode prosperar em vários frutos em benefício para o acusado. Destarte, nessa pauta, o termo inicial colabora o direito na mesma perspectiva de extrema importância para o princípio da legalidade.

Com isso, a prescrição da pretensão executória desvela o prazo para começar a correr a partir do dia a sentença transita em julgado, dessa forma, não será necessário que o prazo de transitar em julgado tenha ocorrido para todas as partes.

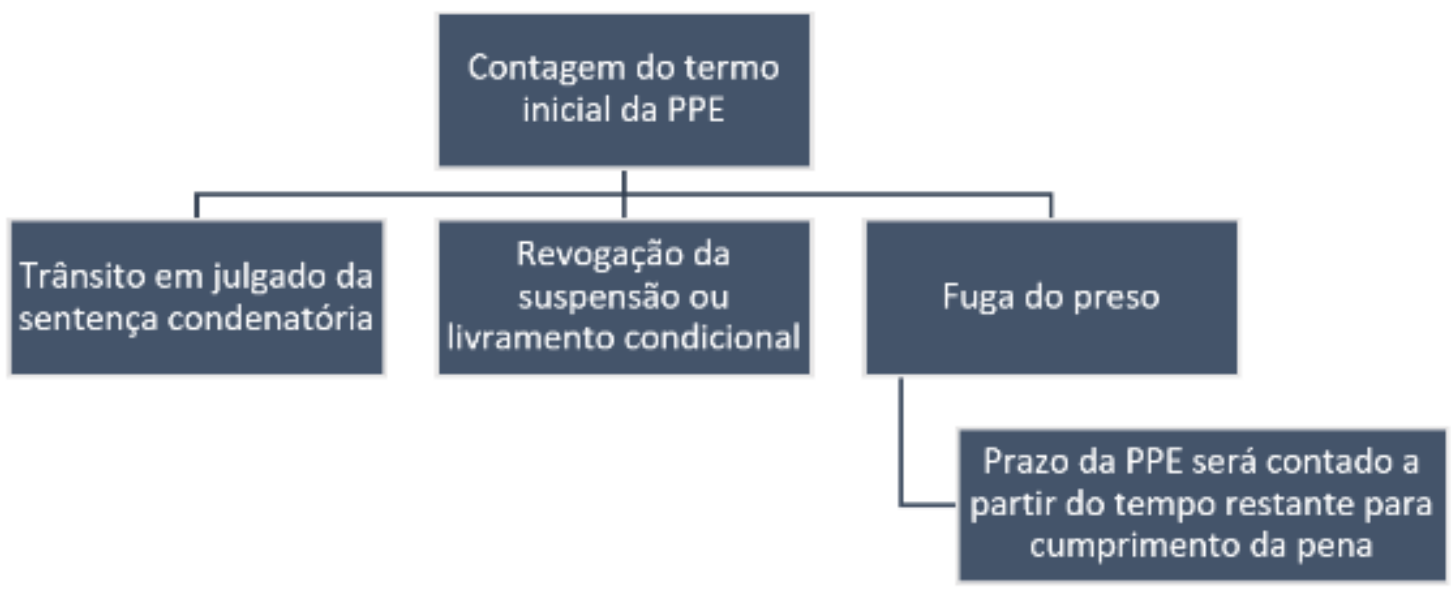

No que tange a revogação da suspensão condicional da pena ou da revogação do livramento condicional, o condenado é concedido em liberdade devido a suspensão ou livramento condicional, todavia, quando se estiver em liberdade e ter quaisquer condutas que enseje na suspensão destas condições. Portanto, nesse sentido, quando 
acontecer de a autoridade revogar a suspensão ou a condição, a PPE irá começará a ser contabilizado.

Quanto a fuga do preso, é importante ressaltar seu sentido, no tocante da interrupção da execução, ao passo que, a partir da data da interrupção se passa a contar a PPE (prescrição da pretensão executória). E por fim, se porventura decorrer o tempo estimado da PPE enquanto ele estiver foragido, ele não poderá mais ser preso.

\section{CAUSAS MODIFICADORAS DO CURSO PRESCRICIONAL}

A priori, as causas modificadoras do curso prescricional poderão ocorrer mediante duas formas, qual seja: causas suspensivas (art. II6 do CP) ou interruptivas (art. II7 do $\mathrm{CP})$.

\section{5.r. CAUSAS SUSPENSIVAS}

Causas suspensivas são aquelas que "pausam" o transcurso da prescrição, ou seja, quando cessam tais causas, a contagem do tempo contínua de onde ela parou.

Hipóteses:

$\rightarrow$ Enquanto o agente cumpre pena em outro país, já que não é possível extraditar neste período.

$\rightarrow$ Exercício de mandato parlamentar, a menos que o Congresso Nacional autorize o processo e cumprimento de pena.

$\rightarrow$ Enquanto houver questão prejudicial em outro processo do qual dependa o reconhecimento do delito. Ex: enquanto um processo tributário não atestar que houve sonegação, não será possível iniciar o processo penal por esse crime, mas ficará suspenso o prazo prescricional enquanto durar a apuração tributária.

$\rightarrow$ Enquanto a pessoa está presa pelo cometimento de outro crime.

$\rightarrow$ Durante a suspensão condicional do processo, conforme artigo 89 da Lei 9.099/95 (sursis processual).

$\rightarrow$ Quando houver citação por edital, enquanto o réu não comparecer ou indicar advogado, conforme artigo 366 do CPP.

$\rightarrow$ Quando estrangeiro for citado por carta rogatória.

$\rightarrow$ Na pendência de embargos de declaração ou de recursos aos Tribunais Superiores, quando inadmissíveis - tentativa do legislador de impedir a prescrição de crimes através de recursos.

$\rightarrow$ Enquanto não cumprido ou não rescindido o acordo de não persecução penal. 


\subsection{CAUSAS INTERRUPTIVAS}

Quando ocorre a interrupção da prescrição, o prazo prescricional tem sua contagem completamente reiniciada, é como se desse um "stop” na contagem.

Exceção: conforme vimos, em caso de fuga do condenado do estabelecimento prisional, a prescrição não começará a correr toda novamente, pois seu tempo será recalculado sobre o tempo de pena que ainda resta a ser cumprida.

\section{Hipóteses:}

$\rightarrow$ Recebimento da denúncia ou queixa - ressalte-se que se trata do recebimento e não do oferecimento. Portanto, considera-se a data do despacho do juiz que recebe a inicial formulada pela acusação.

$\rightarrow$ Pronúncia - Decisão interlocutória com estrutura de sentença que remete os autos ao Tribunal do Júri por considerar presentes todos os requisitos que tornam admissível a acusação feita pelo representante do Ministério Público. É considerada de natureza mista, pois encerra a primeira fase do procedimento do júri (fase de formação da culpa), dando início à segunda fase (preparação do plenário).

$\rightarrow$ Decisão confirmatória da pronúncia - decisão proferida por tribunal quando é interposto recurso (RESE) contra a decisão de pronúncia.

$\rightarrow$ Publicação de sentença condenatória recorrível - desta forma, as sentenças absolutórias, nulas e que concedem perdão judicial não são causas interruptivas.

$\rightarrow$ Publicação de acórdão condenatório recorrível - ocorre quando a sentença absolve mas o acórdão condena (só poderá ocorrer quando a acusação recorrer).

$\rightarrow$ Início do cumprimento da pena ou continuação do cumprimento de pena (retorno do condenado após fuga).

$\rightarrow$ Reincidência - a doutrina majoritária entende que a reincidência ocorre com a sentença condenatória que reconhece a prática do novo ilícito.

\section{PRESCRIÇÃO DA PENA DE MULTA}

Conforme o Código Penal Brasileiro no seu Artigo 49 a pena de multa consiste em:

Art. 49 - A pena de multa consiste no pagamento ao fundo penitenciário da quantia fixada na sentença e calculada em dias-multa. Será, no mínimo, de ıo (dez) e, no máximo, de 360 (trezentos e sessenta) dias-multa. 
Segundo Coelho (2015, p.329), as penas de multa devem ser atualizadas, de acordo com os índices oficiais de correção monetária na época de sua execução, passando a correr a correção monetária a partir da data da sentença.

O Código Penal preceitua no Art. II4, sobre a prescrição da pena de multa. Esse artigo preceitua que quando a pena de multa for a única cominada, ela prescreverá em 2 (dois) anos. Já quando for pena alternativa, cumulativamente cominada ou cumulativamente aplicada, prescreverá no mesmo prazo estabelecido para a prescrição da pena privativa de liberdade.

Art. II4 - A prescrição da pena de multa ocorrerá:

I - em 2 (dois) anos, quando a multa for a única cominada ou aplicada;

II - no mesmo prazo estabelecido para prescrição da pena privativa de liberdade, quando a multa for alternativa ou cumulativamente cominada ou cumulativamente aplicada. (Redação dada pela Lei no 9.268, de Io.4.1996)

De acordo com Cunha (2017, p. 363-364), do art. II4 do CP, extraímos cinco hipóteses no caso de multa, sendo três da pretensão punitiva e duas da pretensão executória.

São hipóteses de prescrição da pretensão punitiva da multa:

\begin{tabular}{|l|l|l|}
\hline Hipótese & Prescrição & Fundamento \\
\hline $\begin{array}{l}\text { Pena pecuniária é a única } \\
\text { cominada. }\end{array}$ & $\begin{array}{l}\text { Opera-se em dois anos, } \\
\text { contados nos termos do art. III } \\
\text { do CP. }\end{array}$ & Art. I14, I, CP. \\
\hline $\begin{array}{l}\text { Pena de multa cominada } \\
\text { cumulativamente com pena } \\
\text { privativa de liberdade. * }\end{array}$ & $\begin{array}{l}\text { Prescreve junto com a pena } \\
\text { mais grave. }\end{array}$ & Art. II8, CP. \\
\hline $\begin{array}{l}\text { Pena de multa cominada } \\
\text { alternativamente com pena de } \\
\text { prisão. }\end{array}$ & $\begin{array}{l}\text { Prescreve junto com a pena de } \\
\text { prisão. }\end{array}$ & Art. II8, CP. \\
\hline
\end{tabular}


*. Ainda que a pena privativa de liberdade seja convertida em restritiva de direitos, não é possível aplicar o art. II4, I, CP. Neste sentido: “A pena restritiva de direitos é de natureza jurídica distinta da pena de multa. Inaplicabilidade, portanto, do inciso I do art. II4 do CP. Disposição legal que estabelece, de modo particularizado, o prazo prescricional de 2 (dois) anos para a pena de multa, quando essa multa "for a única cominada ou aplicada", o que não é a hipótese dos autos”. (STF - Primeira Turma HC ror669 - Rel. Min. Dias Toffoli - Dje 30/ri/2010).

São hipóteses de prescrição da pretensão executória da multa:

\begin{tabular}{|l|l|l|}
\hline Hipótese & Prescrição & Fundamento \\
\hline $\begin{array}{l}\text { Pena de multa aplicada } \\
\text { cumulativamente com pena } \\
\text { privativa de liberdade. }\end{array}$ & $\begin{array}{l}\text { Prescreve junto com a pena } \\
\text { privativa de liberdade, mais } \\
\text { grave. }\end{array}$ & Art. II8, CP. \\
\hline Pena de multa é a única aplicada & $\begin{array}{l}\text { Prescreve em dois anos, } \\
\text { contados da data do trânsito } \\
\text { na sentença. }\end{array}$ & Art. II4, CP. \\
& $\begin{array}{l}\text { em julgado para a acusação. } \\
\end{array}$ & \\
\hline
\end{tabular}

Em relação ao prazo prescricional, entende a maioria da doutrina que, mesmo com o advento da Lei 9.268/96, este continua sendo o do CP (art. II4), aplicando-se a Lei de Execução Fiscal (Lei 6.830/1980) apenas quanto às causas interruptivas e suspensivas da prescrição (art. 5 I do CP). 


\section{CASO CONCRETO SOBRE A PRESCRIÇÃO E SUAS CONSIDERAÇÕES TEÓRICAS}

João Teixeira de Faria, nasceu na cidade Cachoeira de Goiás em 1942. E ficou conhecido como João de Deus no Brasil, por ser um médium com poderes de cura. A maioria das atividades de João foram feitas na cidade de Abadiânia, no estado de Goiás, mas com o passar do tempo ele foi ficando cada vez mais famoso, fazendo excursão por todo o Brasil, inclusive pelo mundo. E com isso, ficou conhecido mundialmente como John Of God ou João de Deus. Nos anos 2000 João fez participação em vários programas de TV e se tornou o médium brasileiro mais famoso da atualidade, todos o amavam e respeitavam. Uma das coisas fundadas por João, foi a Casa Dom Inácio de Loyola, criada em 1976, com o intuito de atender pessoas e fazer orações, atendia mais de 3 mil pessoas por dia, e ao que tudo indica, não cobrava pelas consultas. Porém, depois das sessões as pessoas eram sujeitas a comprar medicamentos, ervas sagradas que curariam e deixariam as pessoas melhores, esses remédios milagrosos eram vendidos na farmácia JTF (João Teixeira Faria). E essa empresa farmacêutica que vendia esses remédios sagrados, pertencia a Ana Keyla de Faria, a atual esposa do médium. Ou seja, os tratamentos eram gratuitos, porém João prescrevia remédios especiais que deveriam ser comprados naquela farmácia para as pessoas se sentirem melhor. Depois de muitos estudos, foram descobertos que muitos remédios não eram nenhuma erva sagrada, se tratava apenas de alguma semente de maracujá, que era vendida por um alto preço, estima-se que com esses remédios João faturava mais de 14 milhões por ano. Não parando por aí, a casa também vendia aguas energizadas e também banhos de cristais, coisas que eram vendidas a parte e que nunca provaram se realmente funcionava. Diferente de Chico Xavier, pois ele dedicou a sua vida ao chamado de Deus, ao espiritismo. Já João de Deus, mesmo sendo um médium, era uma pessoa totalmente comum, cheio de ganancias, e com muita promiscuidade na vida dele. Uma grande promiscuidade que levou ele a ter in filhos, cada um com uma mulher diferente. Devido a tanto dinheiro, João se tornou um grande empresário com propriedades rurais, fazendas, imóveis e também sócio e vendedor de medicamentos manipulados. E segundo as pesquisas João é dono de várias fazendas, sendo a maior 
delas avaliada em 2 milhões de reais, e além das fazendas, é dono de 28 imóveis na cidade de Abadiânia, que são alugadas para seus pacientes, além disso João tem um avião. João já atendeu diversos pacientes famosos, como o ex-presidente Lula, a Dilma e a Xuxa, fora celebridades internacionais.

Aparentemente uma vida de total sucesso, que estava indo muito bem, mas no fundo a não era assim. João não esperava que seus segredos ocultos fossem revelados, e foi isso que acabou derrubando um dos maiores médiuns do Brasil. No dia 7 de dezembro de 2018, Io mulheres acusaram João de Deus de terem sido abusadas por ele, esses crimes teriam acontecido durante as sessões espirituais, na Casa Don Inácio de Loyola. A casa espírita de João de Deus tinha caído, por ao invés dele fazer sessões espiritas ou curar seus pacientes em sua casa, durante suas sessões acabou aproveitando de muitas mulheres. Depois das io mulheres terem se pronunciado durante o programa, várias outras começaram a aparecer e no dia seguinte, um jornal com prestígio publicou mais 3 mulheres que haviam denunciado João de Deus. De acordo com as mulheres, ele dava um jeito de ficar sozinho com elas dentro da sala e falava que elas tinham sido escolhidas por Deus para serem curadas, mas que para alcançar a cura, elas tinham que fazer tudo que João pedisse. Ele então pedia para elas tocarem em suas partes intimas ou as vezes ele tocava nas partes intimas delas, em alguns casos acontecia até pior, João de Deus pedia para as mulheres se deitarem e a estupravam.

Depois que algumas tiveram coragem de denunciar primeiro, poucos dias depois, centenas de denúncias apareceram e foram todas recebidas pelo Ministério Público de Goiás. No meio dessas mais de roo mulheres, havia uma que era filha de João, que relatou em uma reportagem publica, que foi assediada pelo pai quando ela tinha io anos de idade e isso aconteceu durante 4 a 5 anos. Não demorou muito para denúncias do país inteiro aparecer, e até mesmo em outros países, como de mulheres da Alemanha, Austrália, Bélgica, Bolívia, Estados Unidos e Suíça. Com tantas denúncias o Ministério Público teve que montar uma força tarefa para receber e apurar centenas de denúncias do mundo inteiro. Sete dias depois da primeira denúncia, no dia 14 de dezembro de 2018, a justiça decretou a prisão preventiva de João de Deus, um médium de 77 anos, que abusou mais de 300 mulheres e que atualmente conta com mais de 500 
denúncias. A princípio, ele ficou foragido, escondido em um dos seus sítios, na zona rural de Abadiânia, depois de 2 dias foragido se entregou para a polícia. Alguns imprevistos estranhos e paranormais aconteceram, segundo alguns relatos dos investigadores que estavam presentes na delegacia, no momento que ele chegou e começou a depor o computador que estava sendo usado para registrar as alegações, pifou e queimou sem explicação.

Quanto a prescrição do caso supracitado, trata-se da hipótese do art.ıIక do Código penal, que traz a idade do criminoso como uma das possibilidades da redução pela metade da contagem do caso prescricional. No texto do art.II5 diz que quando o criminoso a época do fato for menor de 2I anos e na época da sentença condenatória, for maior que 70 anos, o prazo prescricional será diminuído pela metade. Foi sanciona em 2003, pelo Estatuto do Idoso, a redução da idade de 70 para 60 anos, que passa a valer pelo código penal. Na época que João foi denunciado, ele tinha 77 anos.

No caso de João, os crimes de estupro de vulnerável, estupro e violação sexual mediante fraude. Por exemplo, para o estupro de vulnerável, a prescrição ocorre normalmente em 20 anos; estupro, 16 anos; violência sexual mediante fraude, 12 anos. Assim, para aqueles crimes ocorridos há io, 8 e 6 anos (tempo já reduzido pela metade), respectivamente, João de Deus não poderá mais ser condenado criminalmente.

O Senado Federal votou na alteração da prescrição no crime de estupro, antes se o cidadão cometesse o crime de estupro e fica 20 anos foragido e quando voltar não pode mais ser denunciado e nem condenado. Hoje é um crime imprescritível, a qualquer momento a pessoa que for violentada poderá denunciar o crime e condenado. É um crime inafiançável, é considerado hediondo onde a pena é mais grave e os seus benefícios são reduzidos no cumprimento dessa pena. $O$ crime que prescreve para João é o de dano moral, já que o prazo de prescrição é de 3 anos, e a maioria dos crimes aconteceram há muito mais.

\section{CONCLUSÃO}

Conclui-se que, o presente artigo objetivou abordar sobre o instituto prescrição penal, partindo de conceitos e premissas básicas até a sua aplicabilidade, explanando 
alguns fatos iniciais básicos à luz da doutrina, jurisprudência e lei seca. Adentrou a seara do Estado como detentor do direito punitivo, abordou-se os limites deste poder punitivo, apresentando a linha tênue que divide a prepotência estatal e os direitos e garantias individuais, apontando os limites estatais $e$ as legitimidades de suas intervenções. Com base em todo o conteúdo exposto, é de máxima importância que direitos não permaneçam em seara meramente teórica, devem ser executados de forma efetiva, em benefício ao corpo social.

\section{REFERÊNCIAS BIBLIOGRÁFICAS}

ALEXY, Robert. Teoria dos Direitos Fundamentais. Tradução de Virgílio Afonso da Silva. São Paulo: Malheiros, 2008. p. 38.

ANTOLISEI, Di Francesco. Manuale di diritto penale. Parte generale, i96o, p.531.

BALTAZAR, Antonio Lopes. Prescrição Penal. Bauru/SP: EDIPRO, 2003.

BITENCOURT, Cezar Roberto. Manual de Direito Penal - Parte Geral 7. ed. São Paulo: Saraiva, 2002, v.

DEZEM, Guilherme Madeira. SOUZA, Luciano Anderson de. Comentário ao pacote anticrime: Lei 13.964.2019. I. ed. São Paulo: Thompson Reuters Brasil, 2020, p. 8I.

MARTINELLI, João Paulo Orsini. Lições fundamentais de direito penal: parte geral. 2. ed. São Paulo: Saraiva, 2017. p 987.

MARTINELLI, João Paulo Orsini. Lições fundamentais de direito penal: parte geral. 2. ed. São Paulo: Saraiva, 2017. p rooo/roor.

PACELLI, Eugênio; CALLEGARI, André. Manual de direito penal. 2015. p. 610.

SANTOS, Juarez Cirino dos. Direito penal: parte geral. 9. ed. rev. atual. e ampl. São Paulo: Tirant lo Blanch, 2020. p 662-663.

SOUZA, Luciano Anderson de. Direito penal: volume i: parte geral. São Paulo: Thompson Reuters Brasil, 2019, p. 125. 